\title{
Paleoclimatic Cycles, Sea Level History and Sequence Stratigraphic Elements in Eocene-Oligocene Sediments of BIMOL-1 Well Northern Niger Delta Basin, Nigeria
}

\author{
${ }^{* 1}$ OSOKPOR, J; ${ }^{2}$ EKWERE, UJ; ${ }^{3}$ OTELE, A \\ ${ }^{* 1}$ Department of Earth Sciences, Federal University of Petroleum Resources, PMB 1221, Effurun, \\ Delta State, Nigeria. \\ ${ }^{2}$ Department of Geology, University of Benin, PMB. 1154, Benin City, Edo State, Nigeria. \\ ***Department of Petroleum Engineering and Geoscience Technology, Federal Polytechnic, Ekowe, Bayelsa State, Nigeria. \\ *Corresponding author Email: Osokpor.jerry@fupre.edu.ng
}

\begin{abstract}
Lithofacies succession and palynomorph data trends in BIMOL-1 well in the north-western Niger Delta Basin have been investigated in order to unravel paleoclimatic influence on paleo-sealevel change and facies evolution. Eight lithologic cycles composed of sand and shale were identified. Miospore speciation revealed forty two miospore form species and ten dinoflagellate cyst species. Miospore and dinocyst trends revealed six climate driven sea level cycles that influenced sedimentation and facies distribution and characteristics. Miospore age determination of the succession revealed L-Eocene to L-Oligocene age range. Nine wet and eight dry climate driven transgressive and regressive events were identified, corresponding to sea level rise and to sea level fall correspondingly. Dry climate occasioned continental progradation that generated thick sand intervals, while wet climate triggered sea level rise, generating thinner sand bodies as transgressive sand reservoirs. Seven high stands (HSTs), eight transgressive (TSTs) and eight lowstand (LSTs) systems tracts, distributed within nine sequences were identified. Candidate MFSs, the 50.0 Ma, 48.9 Ma, 46.1 Ma, 43.2 Ma, 41.0 Ma, 34.0 Ma MFSs were identified. Candidate SBs identified include the 50.7 Ma, 48.4 Ma, 47.2 Ma, 44.4 Ma, 42.7 Ma, 40.1 Ma and 32.4 Ma SBs. Early Rupelian sequence boundaries were identified. Erosion/non-deposition of the Priabonian and parts of the Bartonian stage were revealed that inferred erosion/non-deposition of about $7 \mathrm{Ma}$ of sediments in the well area. A synthesis of results of the evaluated proxies revealed that Paleoclimate-driven sea level and paleovegetation trends acted as key facies generators in the well area.
\end{abstract}

\section{DOI: https://dx.doi.org/10.4314/jasem.v23i2.7}

Copyright: Copyright (C) 2019 Oguntolu et al. This is an open access article distributed under the Creative Commons Attribution License (CCL), which permits unrestricted use, distribution, and reproduction in any medium, provided the original work is properly cited.

Dates: Received: 15 August 2018; Revised: 01 January 2019; Accepted 11 January 2019

Keywords: Paleoclimateic cycles, climate driven sea level, Niger Delta, climatic index

Ancient sedimentary successions host a variety of records which may be important in unravelling past sea level and climatic fluctuations. Eocene-Oligocene sediments of the Niger Delta Basin are known to register varied sea level regimes reflected in the cyclic lithofacies pattern of the formational units (Reijers, 2011). The abundance and presence of palynotaxa preserved in sediments has been used as paleoclimatic and paleocenographic proxies for many decades (Jan du Chene and Adediran, 1984; Gregory and Hart, 1992; Lucas, 1992; Elsik, and Yancey, 2000; Adeonipekun, et al., 2012) and the influence of climate on paleovegetation cyclicity and sea level change is well documented (Van Der Hammen, 1957, 1961; Rull and Poumot, 1997; Rull, 2000). Studies have shown that paleoclimatic trends and fluctuations can be revealed by biosignals stored in sedimentary successions. The study of palynotaxa provides beyond age determination, fundamental contributions of our understanding of ancient climatic regimes. The biogeography and diversity of palynotaxa through geologic time varied depending on latitudinal zonation as well as climatic dynamics and variability (McIntyre and Bè, 1967; Findlay and Giraudeau, 2000; Boecked and Baumann, 2008). Changing climate as experienced in the present is observed to drive vegetation trends and global sea level change and patterns. The imprint of this process generates various sedimentary signatures registered as facies depending on the location where such process operates. Tertiary sediments of the Niger Delta Basin display various lithofacies components distributed within different lithostratigraphic units (Short and Stauble, 1967; Avbovbo, 1978, etc.), known to be products of oscillating sea level regimes through geologic time (Reijers, 2011). Several studies on the palynology, sedimentology, paleodepositional environment and sequence stratigraphy etc., on the Niger Delta have been carried out to contribute to the knowledge base of the geology and history of the Delta, but few have been directed towards paleoclimatic and paleooceanographic factors that can be related to sequence stratigraphic framework. In this study, we seek to use biosignals to unearth paleoclimatic cycles

*Corresponding author Email: Osokpor.jerry@fupre.edu.ng 
locked in Eocene-Oligocene sediments of the Niger Delta accessed through well cutting samples retrieved from BIMOL-1 well in the northern Niger Delta Basin. This study is aimed at investigating the paleoclimatic cycles, sea level history and sequence stratigraphic elements in Eocene - Oligocene sediments of BIMOL1 well northern Niger Delta basin, Nigeria. It is envisaged that the cycles can be related to and used to distinguish sedimentary packages that would reflect systems tracts. In the Niger Delta sedimentary pile, individual sea-level cycles are reflected in the various sedimentary sequences and interferences of cycles with different periods result in megasequences that are chronostratigraphically confined and sedimentologically characterised (Reijers, 2011).

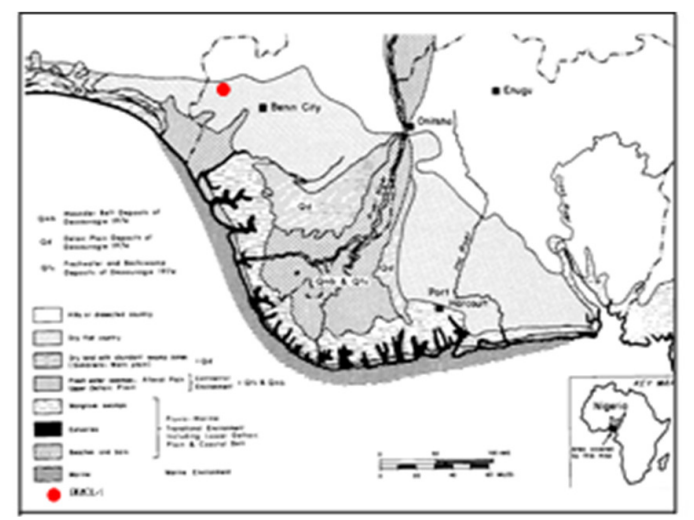

Fig. 1: Generalized map of the Niger Delta showing main sedimentary environments (Allen, 1965; Whiteman, 1982)

Geological Setting of the Niger Delta Basin: The Niger Delta Basin (Fig. 1) stands as one of the most prolific hydrocarbon provinces in the African continent. With a clastic wedge of just over $10 \mathrm{~km}$ thick, (Fig. 2), a very high concentration of petroleum per unit volume of rock is key note. known estimates of the ultimate recoverable hydrocarbons from the Niger Delta province range from $35 \times 10^{9} \mathrm{BBL}$ of oil and $120 \mathrm{x}$ $10^{12} \mathrm{SCF}$ of gas (Ekweozor and Daukoru, 1994) to 66 $\mathrm{x} 10^{9} \mathrm{BBL}$ of oil equivalent (BOE; Saugy and Eyer 2003). For many decades, exploration and production has been concentrated mostly on land or in shallow water, although since 1996 licensing rounds, major deep-water discoveries, of the order of $10^{9} \mathrm{BOE}$, have been made (Agbami, Bonga, Bonga SW, Chota, Erha, Usan, Ukot, Zafiro, Ikija, Etan and Bobo). The sedimentary pile of the Niger Delta Basin has built out over the African Atlantic continental margin and adjacent oceanic crust since Eocene times (Evamy et al., 1978). The sedimentary pile of the basin is subdivided into a three-fold age diachronous stratigraphic subdivision, into the marine Akata, shallow marine Agbada and delta plain Benin formations, which reflects the distinguishing sedimentary environments of a regressive megasequence (Short and Stauble, 1967; Doust and Omatsola 1989; Morgan 2003).

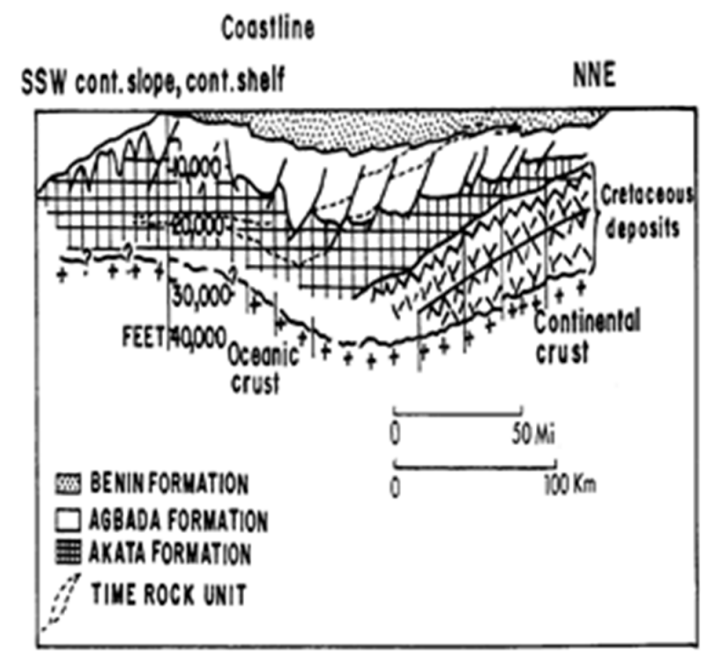

Fig. 2: Schematic subsurface cross section showing the main stratigraphic units of the Niger Delta Basin (after Ekweozor and Okoye, 1980)

The Akata Formation which consists of parallellaminated mud has formed in deep water and, basinfloor, pro-delta setting. Generally the Akata Formation is viewed as the main source sediments for hydrocarbons in the Niger Delta. It is 3-4 km thick and overpressured (Short and Stauble, 1967; Doust and Omatsola 1989; Haack et al., 2000). The Agbada Formation consists of mixed clastic sediment, and is about $3 \mathrm{~km}$ thick or more. The Agbada Formation was formed in a paralic environment. Sediments of the Agbada Formation act as the main reservoir rocks for hydrocarbons generated in the basin. Capping the delta is the Benin Formation which is largely continental and fluvial in origin and consists of mainly sands.

\section{MATERIALS AND METHODS}

Sampling: A total of fifty non-composited ditch cuttings of sand and shale from a near-surface depth of $486-3216 \mathrm{~m}$ of the BIMOL-1 well located in the western reaches of the north-western area of the Niger Delta Basin (Fig. 1), were subjected to whole rock visual grain textural analyses using stereomicroscopic description to determine gross grain characteristic (mineralogy, morphology, sorting, presence of accessory materials, size distribution, and colour). The well under study belongs by Shell Petroleum Development Company (SPDC), but coded BIMOL1 well in this study for confidentiality reasons. For lithofacies description, a sampling range of $18-78 \mathrm{~m}$ (av. $=56.5 \mathrm{~m}$ ) for the upper section of the well (depth range of $486-648 \mathrm{~m}$ ), a sampling range of $18-108$ $\mathrm{m}(\mathrm{av} .=66.71 \mathrm{~m})$ for the mid-section (depth range of 
$828-1674 \mathrm{~m}$ ) and a sampling range of $18-84 \mathrm{~m}$ with an average of $52.50 \mathrm{~m}$ for the lower section (1782 $3216 \mathrm{~m}$ ) of the well was achieved, with a general sampling range of $48.82 \mathrm{~m}$ for the well.

Palynological sample Preparation and Analysis: Thirty five (35) samples from the well section were subjected to series of acid treatment for palynological slide and analysis in accordance with techniques described by Traverse (1988), while age determination is based on earlier works by Muller (1959), Gemeraad (1968), Adegoke (1969), Legoux (1978), and Sowumi (1981b).

\section{RESULTS AND DISCURSION}

Lithostratigraphy: Whole rock lithologic sample description revealed eight distinct lithologic units/successions in the well section as detailed below (Fig. 3):

Unit $1(3216-2970 \mathrm{~m})$ : This unit is composed of $246 \mathrm{~m}$ thick black fossiliferous fissile shale and forms the basal unit of the succession.

Unit $2(2970-2856 \mathrm{~m})$ : This unit is composed of $114 \mathrm{~m}$ thick subangular to subrounded coarse grained sand, and unconformably overlies Unit 1.
Unit $3(2856-2574 \mathrm{~m})$ : This sequence is composed of about $282 \mathrm{~m}$ of black carbonaceous fossiliferous shale.

Unit $4(2574-2484 m)$ : This interval is composed of subrounded - rounded medium to coarse grained sand, sandwiched between thick shale of unit 3 below and unit 5 above.

Unit 5 (2484 - $1674 \mathrm{~m})$ : This unit is composed of $800 \mathrm{~m}$ of black fossiliferous fissile shale. This unit occur as the thickest unit in the well section.

Unit $6(1674-1404 \mathrm{~m})$ : This interval is composed of $730 \mathrm{~m}$ thick subangular - rounded medium to coarse grained sand unconformably overlying shale of unit 5 .

Unit $7(1404-648 \mathrm{~m})$ : This unit is characterized by $756 \mathrm{~m}$ of shale and sand interbeds. The shale interbeds are fossiliferous and displays medium the dark grey colour. The sand interbeds are characteristically composed of subangular - rounded very fine to medium grained sand.

Unit $8(648-486 \mathrm{~m})$ : this unit caps the well section and is also composed of sand and shale interbeds. It is distinguished as a different unit based on the morphological characteristics of the sand components which displays subrounded to well-rounded fine to medium grains and light to medium grey shale interbeds.

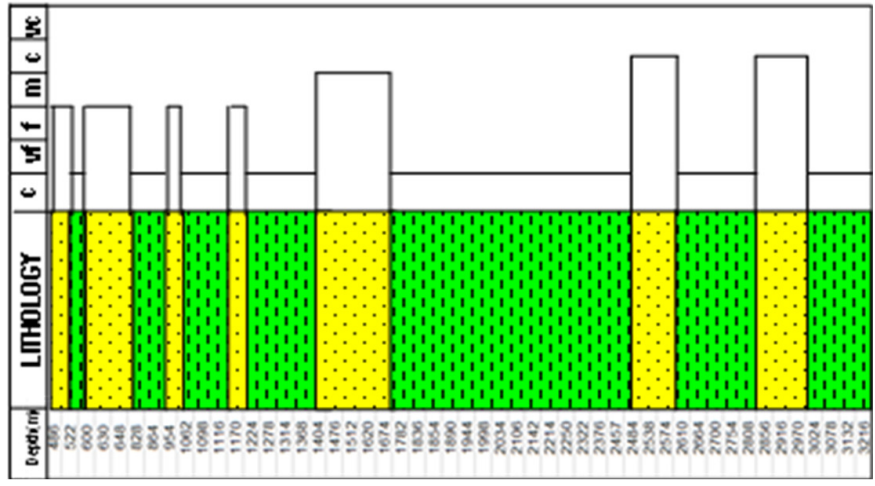

Fig. 3: Lithologic of BIMOL-1 well showing the two main lithologies, sand and shale, in the sections.

$\begin{array}{llr}\text { Quantitative Distribution of Palynological } \\ \text { Constituents: } & \text { The palynological constituents }\end{array}$ recovered from the well were initially classified according to their biological origin as continental and marine forms and further sub-classified into Miospore, fungi which together constitute the allochthonous forms and dinocyst (Fig. 5) which makes up the authochthonous fraction. Quantitative miospore counts in the well ranged from thirty seven (37) to one thousand four and sixty nine (1469), while dinoflagellate cyst species count ranged from one (i) to forty nine (49) at various depth intervals and complete absence in some depth intervals. Quantitative depth distribution of the various form species are presented in Table 1. A total of forty two (42) miospore species and ten (10) dinoflagellate cyst species were identified in this study. 
Table 1: Quantitative depth distribution of miospores and dinocysts from BIMOL-1 well

\begin{tabular}{|c|c|c|c|c|c|}
\hline $\mathbf{S} / \mathbf{N}$ & $\begin{array}{l}\text { Depth } \\
\text { (m) }\end{array}$ & Pollen & Spore & $\begin{array}{l}\text { Total } \\
\text { Miospore } \\
\end{array}$ & Dinocyst \\
\hline 1 & 486 & 100 & 16 & 116 & 0 \\
\hline 2 & 522 & 1434 & 35 & 1469 & 0 \\
\hline 3 & 600 & 196 & 16 & 212 & 0 \\
\hline 4 & 630 & 440 & 13 & 453 & 0 \\
\hline 5 & 648 & 347 & 44 & 391 & 1 \\
\hline 6 & 828 & 77 & 15 & 92 & 2 \\
\hline 7 & 864 & 160 & 16 & 176 & 7 \\
\hline 8 & 954 & 200 & 55 & 255 & 1 \\
\hline 9 & 1062 & 163 & 08 & 171 & 0 \\
\hline 10 & 1098 & 266 & 54 & 320 & 3 \\
\hline 11 & 1116 & 241 & 88 & 329 & 0 \\
\hline 12 & 1170 & 281 & 120 & 401 & 0 \\
\hline 13 & 1224 & 281 & 180 & 461 & 1 \\
\hline 14 & 1278 & 320 & 105 & 425 & 3 \\
\hline 15 & 1314 & 346 & 116 & 462 & 1 \\
\hline 16 & 1368 & 333 & 96 & 429 & 3 \\
\hline 17 & 1404 & 292 & 36 & 328 & 1 \\
\hline 18 & 1476 & 330 & 120 & 450 & 5 \\
\hline 19 & 1512 & 41 & 02 & 43 & 0 \\
\hline 20 & 1620 & 345 & 126 & 471 & 5 \\
\hline 21 & 1674 & 360 & 53 & 413 & 1 \\
\hline 22 & 1782 & 281 & 50 & 331 & 27 \\
\hline 23 & 1836 & 32 & 05 & 37 & 8 \\
\hline 24 & 1854 & 41 & 12 & 53 & 3 \\
\hline 25 & 1890 & 59 & 01 & 60 & 2 \\
\hline 26 & 1944 & 50 & 23 & 73 & 0 \\
\hline 27 & 1998 & 370 & 6 & 435 & 4 \\
\hline 28 & 2034 & 59 & 20 & 79 & 5 \\
\hline 29 & 2106 & 45 & 02 & 47 & 49 \\
\hline 30 & 2142 & 100 & 18 & 118 & 9 \\
\hline 31 & 2214 & 72 & 02 & 74 & 22 \\
\hline 32 & 2250 & 47 & 10 & 57 & 0 \\
\hline 33 & 2322 & 54 & 02 & 56 & 2 \\
\hline 34 & 2376 & 137 & 61 & 198 & 3 \\
\hline 35 & 2457 & 113 & 12 & 125 & 39 \\
\hline 36 & 2484 & 96 & 53 & 149 & 3 \\
\hline 37 & 2538 & 65 & 05 & 70 & 6 \\
\hline 38 & 2574 & 33 & 23 & 56 & 0 \\
\hline 39 & 2610 & 47 & 03 & 50 & 5 \\
\hline 40 & 2664 & 82 & 36 & 118 & 5 \\
\hline 41 & 2700 & 110 & 12 & 122 & 2 \\
\hline 42 & 2754 & 38 & 22 & 60 & 0 \\
\hline 43 & 2808 & 467 & 39 & 506 & 9 \\
\hline 44 & 2856 & 353 & 85 & 438 & 1 \\
\hline 45 & 2916 & 231 & 38 & 269 & 3 \\
\hline 46 & 2970 & 116 & 14 & 130 & 0 \\
\hline 47 & 3024 & 113 & 03 & 116 & 0 \\
\hline 48 & 3078 & 100 & 37 & 137 & 2 \\
\hline 49 & 3132 & 174 & 03 & 177 & 0 \\
\hline 50 & 3216 & 111 & 44 & 155 & 0 \\
\hline
\end{tabular}

Sea level history, Paleoclimate and Climatic cycle: The integration of sedimentological and palynological results from the well enabled valid inferences to be made regarding the age of the sediments, changes in sea level through time and paleoclimatic regime. From graphical analysis of miospore and dinocyst abundance (Fig. 4), inferences concerning sea level history, paleoclimatic changes and cycles were made. This analysis revealed a climate driven cyclic sea level pattern that influenced sedimentation and facies distribution and characteristics.
Sea Level History And Paleoclimatic Changes: Seal level history which is the record of the rise and fall of global sea level above and below its mean datum in past geologic times and driven by paleoclimatic indices which refers to past climatic conditions that prevailed in a given region is defined in this work.

The importance of this record is seen as a rise in sea level is marked by transgression of the sea, during which a landward shoreline shift is recorded and vice versa, thus important in erecting sequence stratigraphic framework for sedimentary columns.

Clues about sea level history and paleoclimate in the well area have been obtained from miospore and dinocysts abundance as proxy indicators, such that a climate driven rise in sea level is marked by wet climatic conditions leading to lush vegetation and high preservation of forms, while the reverse is obtained for seal level fall.

The result of the graphical analysis of the plot of miospore and dinocysts quantitative signatures with depth (Fig. 4) reveals changes in the paleo sea level and paleoclimate in the well section in which sea level rise alternates with seal level fall at various depths, revealing a cyclic pattern. In this signature, a rise and fall in sea level corresponds to wet and dry climatic conditions respectively (Table 2, Fig. 7).

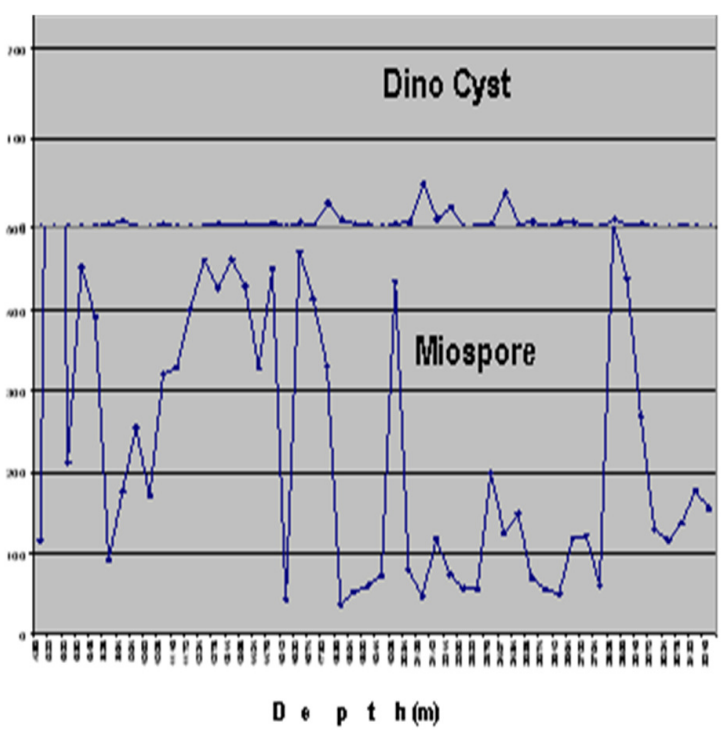

Fig. 4: Graphical depth plots of miospore and dinoflagellate cysts in BIMOL-1 well 


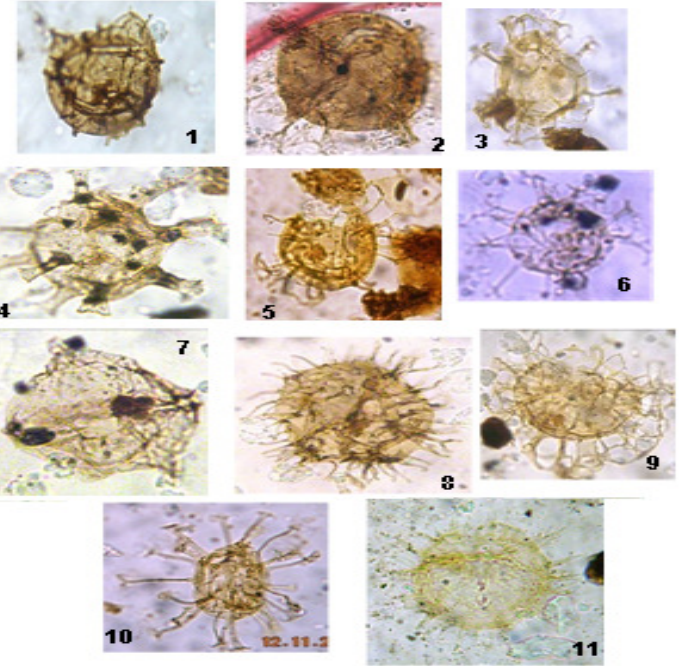

Fig. 5: Photomicrograph of some of the age-significant and paleoenvironment diagnostic dinocyst species recovered from the well section. (1. Kenleyia lophophora, 2. Muratodinium fimbratum, 3. Homotryblium tenuispinosum, 4. Homotryblium palladium, 5. Systematophora, 6. Spiniferites pseudocatus, 7. Palaeoperidinium, 8. Apectodinium homomorphum, 9. Adnatosphaeridium vittatum. 10. Distatodinium. 11. Lingulodinium macphaerophorum.)
Climatic Cycles and Reservoir Typing: A sequence of wet-dry-wet climatic index or dry-wet-dry climatic index gives a complete climatic cycle. Based on the miospore signal in figure 7 , six climatic cycles have been identified: first climatic cycle ranged from 3216 to $2797 \mathrm{~m}$, second cycle ranged from 2797 to $2567 \mathrm{~m}$, third cycle ranged from 2567 to $2286 \mathrm{~m}$, fourth cycle ranged from 2286 to $1634 \mathrm{~m}$, fifth cycle ranged from 1634 to $1107 \mathrm{~m}$ and the sixth cycle ranged from 1107 to $486 \mathrm{~m}$. The climatic cycles stands as facies generators in the sedimentary sequence. In this vain, sand bodies formed during a rise indicates a transgressive reservoir, as a rise in sea level corresponds to transgression while sand bodies formed during a fall in sea level corresponds to regressive sands such as lowstand sand wedge. The importance of this differentiation is appreciated in systems tract reservoir characterisation, in which reservoirs formed in different systems tract are known to possess different reservoir characteristics that ultimately determine the exploration and production philosophy of each reservoir type (Catuneanu, 2006).
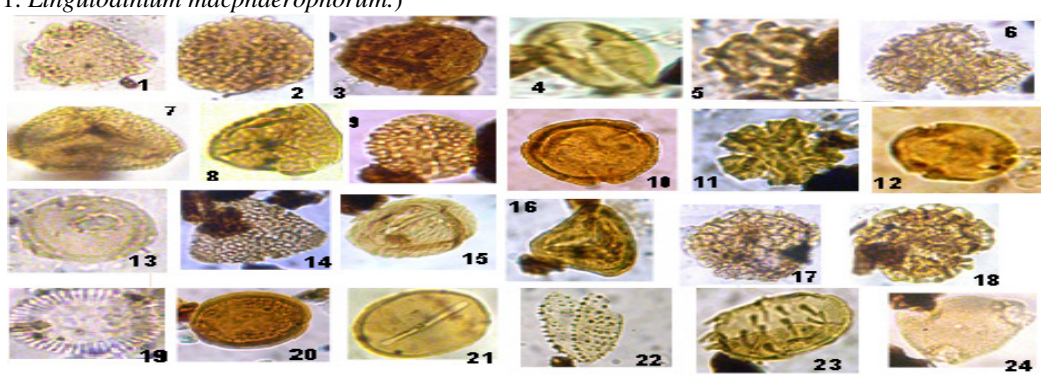

Fig. 6: Photomicrograph of some of the age-significant and paleoenvironment diagnostic miospore species recovered from the well section. (1. Retribrevitricolpites triangulates, 2. Cleistophollis patens, 3. Mauritiidites lehmani, 4. Monocolpites sp., 5. cf. baculatus, 6. Retitricolporites irregularis, 7. Fenestrate pollen, 8. Filtrotrilete nigerensis, 9. Retricolpites sp., 10. Psilatricolporites crassus, 11. Ctenolophonidites costatus, 12. Psilatriporites sp. 13. Sporopollenites pollen. 14. Syndemicolpites typicus, 15. Striatricolpites catatumeus, 16. Polypodiacesporites sp., 17. Praedapollis africanus, 18. Praedapollis flexibilis, 19. Ancillary microfossil, 20. aff. Nymphea lotus linn, 21. Psilamonocolpites marginatus, 22. Echimonocolpites rarispinosus, 23. Spinizonocolpites echinatus, 24. Retribrevitricolporites. Obodensis.)

Table 2: Sea level and climatic index versus depth recognized in the well section

\begin{tabular}{lll}
\hline Depth (m) & $\begin{array}{l}\text { Sea Level } \\
\text { History }\end{array}$ & $\begin{array}{l}\text { Climatic } \\
\text { Index }\end{array}$ \\
\hline $600-486$ & Rise & Wet \\
$648-600$ & Fall & Dry \\
$1107-648$ & Rise & Wet \\
$1197-1107$ & Fall & Dry \\
$1503-1197$ & Rise & Wet \\
$1654-1503$ & Fall & Dry \\
$1971-1654$ & Rise & Wet \\
$2016-1971$ & Fall & Dry \\
$2286-2016$ & Rise & Wet \\
$2363-2286$ & Fall & Dry \\
$2565-2363$ & Rise & Wet \\
$2637-2565$ & Fall & Dry \\
$2727-2637$ & Rise & Wet \\
$2795-2727$ & Fall & Dry \\
$2997-2795$ & Rise & Wet \\
$3153-2997$ & Fall & Dry \\
$3216-3153$ & Rise & Wet \\
\hline
\end{tabular}

Age Calibration and Lithostratigraphic Differentiation: The geologic age of the sediments was determined by index forms identified among the many pollen and spores recovered from the well. These include: Cleistopholis patens, Pachydermites diederixi, Grimsdalea polygonalis, Grimsdalea magnaclavata, Cyathidites sp., Verrucatosporites sp., Retibrevitricolporites triangulates, Retibrevitricolporites obodoensis, Praedopollis africanus, Praedopollis flexibilis, Polypodiaceisporites sp., Racemonocolpites hians, Cinctiperiporites mulleri, Arecipites exilimuratus and Proxapertites cursus.

An age evaluation of these forms revealed a Lower Eocene to Lower Oligocene age range for the sediments as detailed below: 
Lower Eocene 3216 - $2832 \mathrm{~m}$ : The low abundance and subsequent disappearance of Cyathidites $s p$., at this depth interval indicate Lower Eocene. This age is also confirmed by the interval being immediately below the first appearance datum of Middle Eocene markers Cleistophollis patens and Pachydermites diederixi (Fig. 6). Other forms that occur within this interval include Zonocostites ramonae, Laevigatosporites sp. and Monolete spores.

Middle Eocene 2832 - $1782 \mathrm{~m}$ : The interval is characterized by the first appearance of Cleistophollis patens, Praedopollis Africans and Pachydermites diederixi (Fig. 6), which indicate Middle Eocene (Legoux, 1978). The occurrence of Grimsdalea polygonalis within this interval further confirms s this age. Other palynomorphs that characterize this interval include Retibrevitricolporites obodoensis, $R$. triangulates, Retitricolporites irregularis, and Laevigatosporites $\mathrm{sp}$. These forms, according to Adegoke, (1969) are common in the Middle Eocene but not endemic to it.

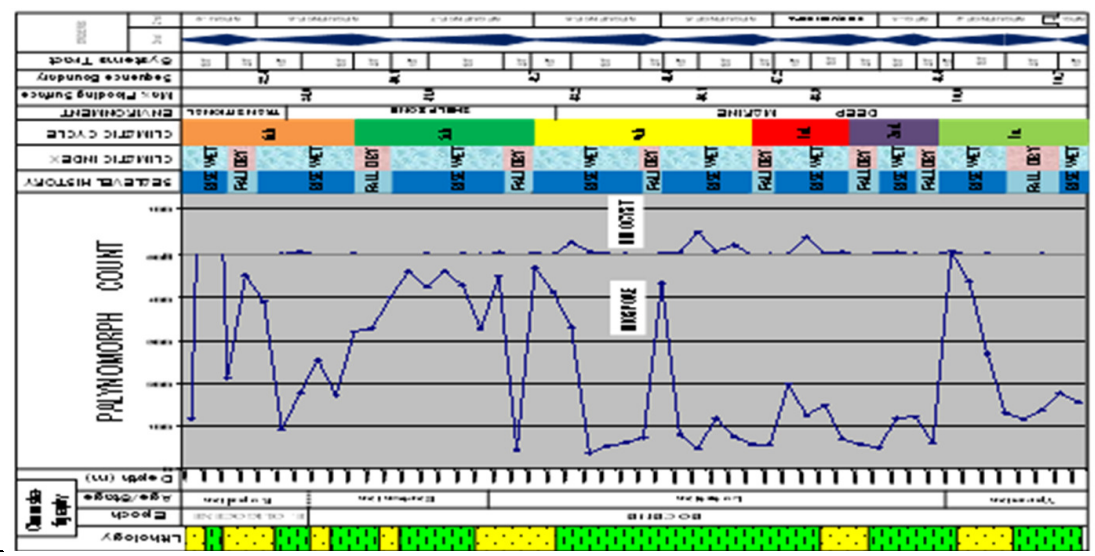

Fig. 7: Quantitative Plots of miospore and dinocyst reflecting changes in sea level, paleoclimate, paleoenvironment and sequence stratigraphic elements recognized in the well section

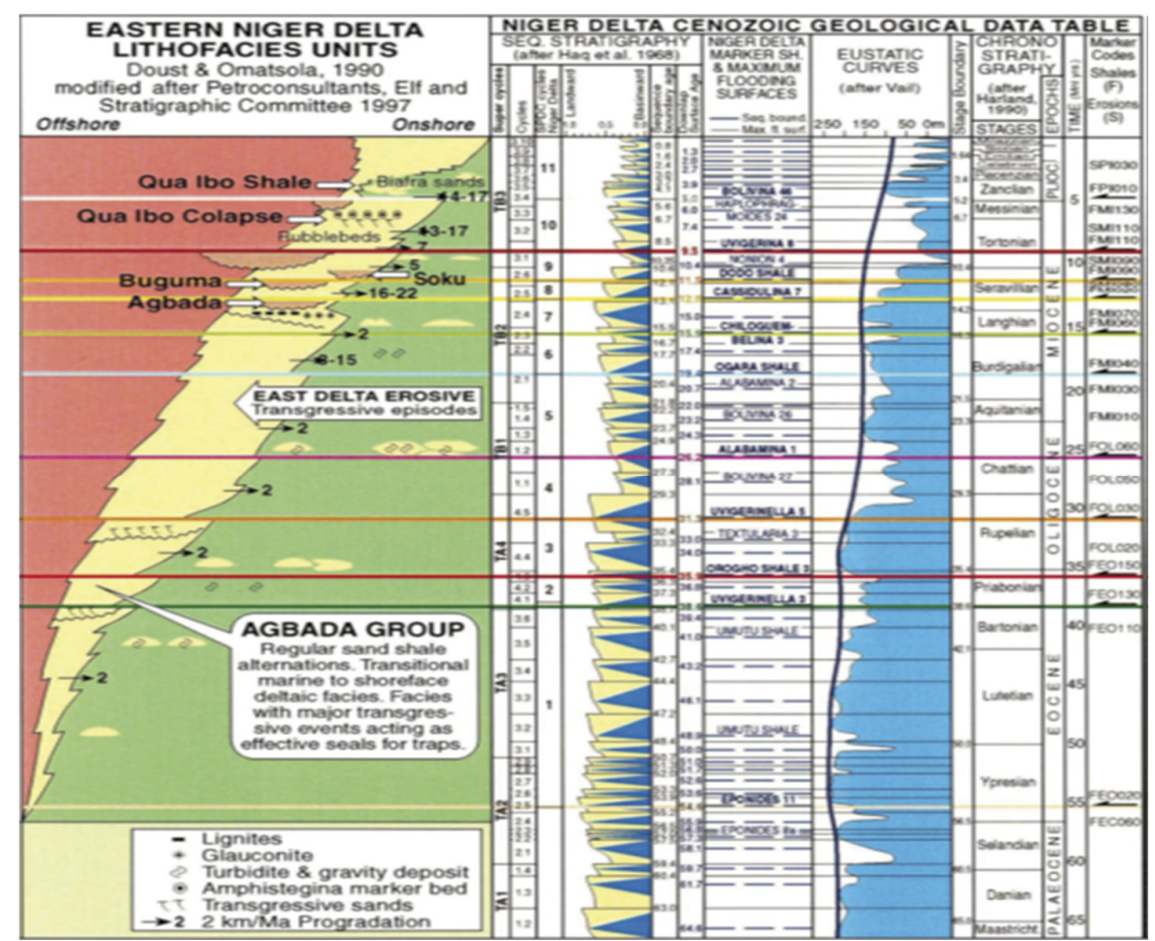

Fig. 8: Chrono-Stratigraphic data sheet (west and east halves combined) of the Niger Delta (SCiN Chrono Chart in Reijers, 2011). 
Upper Eocene 1782 - $954 \mathrm{~m}$ : This interval is characterized first by the stratigraphic appearance of Racemonocolporites hians and Cinctiperiporites mulleri which indicate Upper Eocene. Muller (1959) asserted these forms to be characteristic of this age. Other formsrecovered from this interval include Polypodiaceisporites sp., Retibrevitricolporites obodoensis and Retimonocolpites obaensis, (Fig. 6). These forms according to Sowumi (1981) are characteristics of Upper Eocene, but not restricted to it.

Lower Oligocene 954 - $486 \mathrm{~m}$ : This interval is characterized by regular and increased occurrence of Arecipites exilimuratus. The regular and increased occurrence of this form indicates that this interval is Lower Oligocene. Other Forms recovered from this interval include Retitricolporites irregularis and Verrucatosporites $s p$.

Sequence Stratigraphy: Twenty three systems tracts made up of seven high stands and eight transgressive and eight lowstand systems tracts, distributed within nine sequences have been identified. Six candidate maximum flooding surfaces (MFS) based on age dates defined by age significant palynotaxa and constrained with the Shell Company in Nigeria (SCiN) Chronochart (Reijers, 2011), include the 50.0 Ma Late Ypresian MFS which marks the close of the Ypresian stage; the $48.9 \mathrm{Ma}, 46.1 \mathrm{Ma}$ and $43.2 \mathrm{Ma}$ MFSs of Lutetian stage (Figs. 7 and 8). Others include the 41.0 Ma Bartonian and the 34.0 Ma Rupelian MFSs. The Priabonian and parts of the Bartonian stage in the well seems to have experienced some form of erosion/nondeposition. This observation is made visible by the systems tracts and the age of the sediments formed within that section of the well, as four maximum flooding surfaces (MFS 39.4, 38.6, 36.8 and 35.9 Ma) are absent in the well section, thus indicates the nonexistence of the upper Bartonian and the entire Priabonian stage of the Late Eocene which accounts for the erosion/non-deposition of about $7 \mathrm{Ma}$ of sediments in the well area and probably marking a major sequence boundary dated 40.1 Ma in this well (Figs. 7 and 8). Seven candidate sequence boundaries (SB) dated 50.7 Ma and of Ypresian stage, 48.4 Ma of Early Lutetian, 47.2 Ma and 44.4 Ma of Mid Lutetian, and 42.7 Ma Late Lutetian were recognized (Figs. 7 and 8). Others include the 40.1 Ma Bartonian and the 32.4 Ma Early Rupelian sequence boundaries.

Conclusions: Palynotaxa record reveals paleovegetational trends which reflect paleoclimatic records and consequent sea level cycles. These correlated with paleovegetational change signatures, indicating that paleovegetational change is occasioned by paleoclimatic change in ancient geologic history that correspondingly affected sea level cycles. Acting as key facies generating elements, in that the thicker sand intervals/successions are closely related to dry climatic periods (sea level fell) and progradation which heralded the sedimentation pattern and vice versa. Sea level trends and climatic conditions correlated with different systems tracts depending on the climatic regime, thus this technique would enable tracking of significant events in the sedimentary history.

\section{REFERENCES}

Adegoke, OS (1969). Eocene stratigraphy of southern Nigeria. Mem. Bur. Recch Geol. Mins. 69, 23-46.

Adegoke, OS (1977). Stratigraphy and paleontology of Ewekoro Formation (Paleocene) of southwestern Nigeria. Bull. Am. Paleontol. 71, 1-397

Adeonipekun, PA; Ehinola, OA; Yussuph, IA; Toluhi, A; Oyelami, A (2012). Bio-Sequence stratigraphy of Shagamu quarry outcrop, Benin Basin, southwestern Nigeria. World Applied Sci. Jour. 18(1), 91-106

Allen, JRL (1965c). Late Quaternary Niger Delta, and adjacent areas: Sedimentary environments and lithofacies. AAPG Bull. 49, 547-600.

Avbovbo, AA (1978). Tertiary lithostratigraphy of Niger Delta. AAPG Bull. 62, 295-306.

Boeckel, B; Baumann, K-H (2008). Vertical and lateral variations in coccolithophore community structure across the subtropical frontal zone in the South Atlantic Ocean. Marine Micropaleo. 67, 255-273.

Catuneanu, O (2006). Principles of sequence stratigraphy. Elsevier, New York.

Doust, HE; Omatsola, EM (1989). "The Niger Delta: Hydrocarbon potential of a major delta province". Prod. KNGMG symp. Coastal lowlands, Geol. \& Geotech. (1987), Kluwer Acad. Publ. 203-212.

Doust, HE; Omatsola, EM (1990). Niger Delta. In: Divergent/passive basins. Edwards, J D; Santagrossi, P A (eds). AAPG Bull. Memoir 45, 201-238.

Elsik, WC; Yancey, TE (2000). Palynomorph biozones in the context of changing paleoclimate, Middle Eocene to Lower Oligocene of the northwest Gulf of Mexico. Palynology. 24, 177-186

Ekweozor, CM; Daukoru, EM (1994). Northern delta depobelt portion of the Akata-Agbada petroleum system, Niger Delta, Nigeria. In: Magoon, LB; Dow, WG (eds) The Petroleum System-From Source to Trap, AAPG Memoir 60, 599-614. 
Ekweozor, CM; Okoye, EM (1980). Petroleum source-bed evaluation of Tertiary Niger Delta. AAPG Bull. 64, 1511259.

Evamy, DD; Haremboure, J; Kamerling, P; Knaap, WA; Molloy, FA; \& Rowlands, PH (1978). Hydrocarbon habitat of Tertiary Niger Delta. AAPG Bull. 62, pp. 139.

Findlay, CS; Giraudeau, J (2000). Extant calcareous nannoplankton in the Australia sector of the southern ocean (Austral summers 1994 \& 1995). Marine Micropaleo., 40, 417-439.

Germeraad, JH; Hopping, CA; Muller, J (1968). Palynology of Tertiary sediments from Tropical areas. Rev. Palaeobotany and Palynol. 6(3/4), 189-348.

Gregory, WA; Hart, GF (1992). Towards a predictive model for palynologic response to sea level changes. Palaios, 7: 3-33.

Haack, RC; Sundararaman, P; Diedjormahor, JO; Xiao, H; Gant, NJ; May, Kelsch, ED (2000) Niger Delta petroleum systems, Nigeria. In: Mello, MR; Katz, BJ (Eds), Petroleum systems of South Atlantic margins. AAPG Memoir, 73, 213-231.

Hedberg, HD (ed.) (1976). International Stratigraphic Guide: A guide to stratigraphic classification, terminology, and procedure: International Subcommission on Stratigraphic classification of IUGS Commission on Stratigraphy. John Wiley and Sons, NY. 200.

Jan Du Chene, RE; Adediran, SA (1984). Late Paleocene to early Eocene dinoflagellates from Nigeria. Cahiers de Micropaleontologie, 3, 1-38.

Legoux, O (1978). Quelques especes de pollen caracteristiques du Neogene Nigeria. Bull. Cent. Rech. Explor. Prod. Elf Aquitaine, 2(2), 265-317.

Lucas, FA (1992). Eustatic sea-level changes as exemplified by palynomorphs in the Anambra Basin. Book of abstracts, 10th annual international conference of NAPE 6.

McIntyre, A; Bè, AHW (1967). Modern coccolithophores of the Atlantic Ocean-I. Placolith and cyrtoliths. Deep Sea Research, 14, 561-597.
Morgan, R (2003). "Prospectivity in ultradeep water: The case for petroleum generation and migration within the outer parts of the Niger Delta apron". In: Arthur, TJ; McGregor, DS; Camerrn, NR (eds). Petroleum geology of Africa: New Themes and Developing Technologies. GSL. Special Publication, 207, 154-164.

Muller, J (1959). Palynology of recent Orinoco Delta and shelf sediments. Reports of the Orinoco Shelf expedition, Micropaleo. 5(1), 32.

Poumot, C (1989). Palynological evidence for eustatic events in the tropical Neogene: Bulletin des Centres de Recherches Exploration-Production Elf Aquitaine, 13, 437-453.

Reijers, TJA (2011). "Stratigraphy and sedimentology of the Niger Delta”. Geologos. 17(3), 133-162.

Rull, V; Poumot, C (1997). Eocene to Miocene palynocyclesfrom western Venezuela, and correlations with global eustatic cycles: Memorias VIII Congreso Geolo'gico Venezolano, 2, 343-349.

Rull, V (2000a). Ecostratigraphic study of Paleogene and Early Eocene palynological cyclicity in northern South America. Palios. 15, 14-24.

Saugy, L; Eyer, JA (2003). Fifty years of exploration in the Niger Delta (West Africa). In: Halbouty, MT (ed) Giant oil and gas fields of the decade 1990-1999. AAPG Memoir, 78, 211-226.

Short, K. C; Stauble, AJ (1967). Outline of geology of Niger Delta. AAPG Bull. 51, 5, 761-779.

Sowunmi, MA (1981b). Aspects of Late Quaternary vegetation changes in West Africa. J. Biogeography, 8 , 457-474.

Traverse, A (1988). Paleopalynology. Unwin Hyman, Boston, MA.

Van Der Hammen, T (1957). Climatic periodicity and evolution of South American Maastrichtian and Tertiary floras: Boletı'n Geologico, 5, 49-91.

Van Der Hammen, T (1961). Upper Cretaceous and Tertiary climatic periodicities and their causes. Annals of the New York Academy of Sciences, 95, p. 440-448.

Whiteman, AJ (1982). Nigeria, its petroleum geology, resources, and potential (1st Edn.). Graham and Trotman Ltd., London. 